\section{War and the Austrian School: applying the economics of the Founders}

\section{Scott A. Kjar and William L. Anderson}

n this article, we examine the economic thoughts of the three founders of the Austrian School, Carl Menger, Eugen von Böhm-Bawerk, and Friedrich von Wieser, and apply their thinking to the economics of war. Each developed analyses that provide foundations for the Austrian School and help explain the school's antiwar perspective. The early Austrians were not pacifists, but their views enable us to read between the lines as to how they would see war, and especially the aggressive wars we see today from the United States.

\section{Menger's paradigm}

Carl Menger's 1871 [1976] book, Principles of Economics (the Grundsätze der Volkswirtschaftslehre in the German title), challenged existing economic orthodoxy by affirming and rejecting ideas found in two major economic schools of thought of the time, the German Historical School and the British Classical School. On the one hand, Menger recognized the crucial role played by economic institutions in shaping an economy, but Menger's analysis was both theoretical and reality-based. Like the classicals, Menger believed that a growing free-market economy advanced civilization, but he broke with them on value theory.

Before establishing value theory, however, Menger first establishes what he calls the Theory of the Good. It consists of four important elements (p. 52). There must be:

- a human need;

- such properties as render the thing capable of being brought into a causal connection with the satisfaction of this need;

- human knowledge of this causal connection; and

- command of the thing sufficient to direct it to the satisfaction of the need.

Menger bases Grundsätze on human needs and their satisfaction. First, he defines goods as things that satisfy human needs, and marginal utility as the extent to which a good satisfies a human need. Value concerns the relative scarcity of that good. Thus, a good which satisfies an important need, satisfies it well, and is highly scarce has high value; a good which satisfies a less-important need, or satisfies it poorly, and (or) is not particularly scarce has a low value. However, a thing that cannot be brought into such a causal relationship provides no utility, so it has no value. All human action, wrote Menger, is involved with bringing goods into such causal relationships.
Although Menger did not write about war, we can apply this analysis to war, its implements, and the human labor of war. Most important, a "good" must meet a human need, and that includes weapons. For example, a military rifle is a good in the Mengerian sense only if it enables someone to meet his or others' needs. Military hardware has value only in its relationship to satisfying particular human needs, not by providing employment in war goods industries or in stimulating an economy.

Aggressive war contradicts Menger's most foundational points. ${ }^{1}$

Like Adam Smith, he wishes to promote civilization, not destroy it. Furthermore, war goods are not Mengerian goods outside of their direct relationship in meeting an individual's needs for defending oneself. However, Menger also described what he called imaginary goods, which people wrongfully believe will satisfy their needs. Menger thought that people could believe that the good satisfies a need when, in fact, it does not, such as drinking salt water to quench one's thirst. People also could believe a good satisfies a nonexistent need, and we place aggressive war and those things used to achieve it into that category.

\section{Austrian economics and classical views of production and consumption}

As mentioned, Menger and his Austrian followers were not pacifists nor against all wars. While they do not address war itself, neither does their economic thought endorse the notion of war prosperity. One classical economist who did comment on war, however, was J.B. Say. ${ }^{2}$ His eponymous law, a pillar of classical economics, acknowledges that consumption in an economy depends upon what that society can produce. The relationship of Say's Law to the Austrian views of putative war prosperity is important and often overlooked. For example, Higgs (1992, p. 53) challenges the view that World War II was economically good for the United States:

"After bearing substantial costs of relocation, the migrants (war industry workers) often found themselves crowded into poorer housing. Because of the disincentives created by rent controls, the housing got worse each year, as landlords reduced or eliminated maintenance and repairs. Transportation, even commuting to work, became difficult for many workers ... Shoppers bore substantial costs of searching 
for sellers willing to sell goods ... The government exhorted the public to 'use it up, wear it out, make it do, or do without.' In thousands of ways, consumers lost their freedom of choice."

While unemployment was low during World War II, real deprivation prevailed in the United States (and was worse in Europe and Japan, obviously). Austrians interpret Higgs as noting that the war economy kept people from meeting their needs. Although the macro statistics showed high levels of GDP production, aggregate demand of wartime production did not create prosperity, which is consistent with Say's Law.

Say himself wrote harshly about war (1826, pp. 430-431):

"War costs a nation more than its actual expense; it costs besides all that would have been gained, but for its occurrence ... To conclude: the charges of war would be very incorrectly estimated, were we to take no account of the havoc and destruction it occasions; that for one at least of the belligerents, whose territory happens to be the scene of its operations, must be exposed to its ravages. The more industrious the nation, the more does it suffer from warfare. When it penetrates into a district abounding in agricultural, manufacturing, and commercial establishments, it is like a fire in a place full of combustibles; its fury is aggravated, and the devastation prodigious. Smith calls the soldier an unproductive labourer; would to God he were nothing more, and not a destructive one into the bargain! He not only adds no product of his own to the general stock of wealth, in return for the necessary subsistence he consumes, but is often set to work to destroy the fruits of other people's labour and toil, without doing himself any benefit."

Like Adam Smith (1976), Say believed that the end of production was consumption. Indeed, while the Austrians broke from the classicals on value, they did not abandon classical views on production and wealth. In fact, Menger links "higher levels of civilization" with increases in the making of goods and the expansion of uses of capital (p. 53) and one must doubt that he meant war goods.

As for the capitalist system needing war in order to provide adequate aggregate demand for goods, Menger and the other Austrians were squarely in the camp of most of the classical economists who differed from Marxists and others that a market economy could not provide enough effective demand to stay afloat by itself. Sowell (1985) notes that those intellectual lines had been drawn early in the nineteenth century.

The classical/Austrian view departs from a Keynesian-type belief that war stimulates the economy, and prevents Austrians from seeing war as enabling economic growth. Instead, they see war as diverting both resources and useful labor from productive to unproductive ends.

\section{Menger, Böhm-Bawerk, capital theory, and its relation to war}

Capital theory begins early in Menger's Principles when Menger contradicts Smith's argument in the opening lines of Wealth of Nations: "The greatest improvement in the productive powers of labour, and the greater part of the skill, dexterity, and judgment with which it is anywhere directed, or applied, seem to have been the effects of the division of labor." Menger conducts a thought experiment concerning two tribes, one an Australian tribe of hunters and fishermen, and the second a more forward-looking group. The first tribe has virtually no capital, although its members have a complete division of labor, albeit "gathering those goods of lowest order that happen to be offered by nature” (p. 73). Menger's second tribe develops capital and investigates "the ways in which things may be combined in a causal process for the production of consumption goods, take possession of such goods, and treat them as goods of higher order" (p. 74). In other words, the second tribe produces capital to increase future production of consumption goods.

Menger emphasizes knowledge in two ways. First, humans must have knowledge of their future needs and of the goods they will desire in the future. Second, they must have knowledge of how to combine resources into tools and capital structures for production of future consumption goods. Through these improvements in knowledge, Menger claims, humanity progresses, as higher-order goods produce the lower-order or consumer goods that meet the needs of individuals, which ultimately develops civilization. Menger, who wrote often of "causal connections," obviously equated the growth of civilization with the increase in forward-looking behavior and knowledge. Taken together, these cause the growth of an economy, and especially an economy that meets the needs of individuals on a wide scale.

However, cannot war increase wealth through plundering others? For example, William Shirer (1941) writes of looting by German soldiers in 1940 after they overran the Low Countries and France in their spring offensive, taking goods back to Germany, where consumer goods were extremely scarce. But plunder is not prosperity, and war and plunder do not advance civilization. A society that lives by plunder, even if it has sufficiently wealthy neighbors, cannot raise its standard of living above those of its neighbors. In turn, neighbors cannot raise their own living standards because they cannot increase their structure of production and, ultimately, everyone becomes poorer.

While Menger developed a basis for capital theory, another Viennese economist Eugen von Böhm-Bawerk, took it further. His main work, Capital and Interest, came in two volumes, History and Critique of Interest Theories (1884), and The Positive Theory of Capital (1889). Garrison (1999) points out that Böhm-Bawerk emphasized the role of time in capital theory: "Production takes time, and the time that separates the formulation of multiperiod production plans and the satisfaction of consumer demands is bridged by capital" (p. 115) and adds that "Böhm-Bawerk indicates that in a market economy it is the entrepreneurs who bring such structural changes about 
and that their efforts are guided by changes in the relative prices of capital goods" ( $\mathrm{p}$. 119).

Austrians hold that entrepreneurs bear the uncertainty of future states. If consumers change their desires, entrepreneurs must be prepared to change their capital structures, and even the goods they produce. In wartime, consumers (specifically, consumer preferences and demand) do not guide production. Instead, the state directs production toward war ends, and entrepreneurs earn profit not by meeting desires of consumers, but by pleasing the government.

Böhm-Bawerk's capital theory emphasizes that the time preference of individuals helps determine the structure of capital goods. Time preference is the extent to which people desire to control resources now instead of in the future. A high time preference rate (TPR) indicates a strong desire to control and consume resources now; a low TPR demonstrates willingness to forgo present consumption in favor of future consumption.

People with low time preference will save now and wait for future goods, which are produced through a longer capital structure. That lower time preference rate releases scarce resources used for current consumption, making them available for capital formation. As the economy increases its capital, this lengthens the structure of production and leads to long-term efficiencies. Entrepreneurs engage in ever-longer time horizons, create ever-more-productive capital structures, and enrich society in the long run. War, on the other hand, brings short-term thinking. It destroys property and lives and also changes the capital structure to create war goods, affecting production for a long time. This is not just because war destroys property, but also because it creates internal economic dislocations that change the direction of production and the relative value of resources.

Austrians emphasize the heterogeneity of capital. Factors of production like unskilled labor are non-specific factors that can be used in many production processes with little loss of productivity. However, capital can be specialized, often minutely specialized. Wartime capital structures differ greatly from those in peacetime. As resources flow to a capital structure that produces war goods, they are lost to an alternate capital structure that could have produced consumer goods and cannot be easily transferred to civilian use after the war ends.

Böhm-Bawerk's greatest legacy is found to be in the areas of heterogeneous capital and interest, and he recognized that time is an important consideration in all production. Further, Böhm-Bawerk noted that in some cases, a faster production process might produce less than a slower one using more stages of production. For example, a person can go fishing right now, and try to catch fish by hand. Another person might find a stick, sharpen it with a stone, and use the subsequent spear to catch fish. It takes longer to start fishing, but the second person catches more fish. Böhm-Bawerk termed the latter processes more "roundabout."

Böhm-Bawerk pointed out that roundabout processes involved more time, more long-term planning, more capital, and more stages of production. Less roundabout processes might produce fewer products faster; more roundabout processes take longer, and are only adopted when they are more productive. In the long run, more roundabout production processes increase society's standard of living.

Roundabout production is related to time-preference rates. A society dominated by individuals with high-TPR will have leaders that rush into decisions and will lead a government that tries to consume beyond its means. For example, before rushing United States armed forces into war in Iraq, U.S. Secretary of Defense Donald Rumsfeld famously said in the United States "you go to war with the Army you have."3 Conversely, a society dominated by low-TPR people is less likely to rush into war and will seek ways to avoid destructive conflict.

During war, military leaders exhibit high TPR. They want war goods now, and are less likely to look out for the welfare of their own soldiers or civilians. The military does not concern itself with how its high-TPR actions will affect the structure of production, as capital moves from civilian production and the standards of living fall (even as GDP rises). In addition, it is clear that in peacetime, military authorities demonstrate more long-term thinking, if only to be preparing for what they believe will be the next war. Austrians would believe that the ensuing military-industrial complex is harmful to an economy, especially in the long-run, because it permanently alters the structure of production and leads businesses from producing those goods that meet the needs of individuals - and advance the cause of civilization - and shifts long-term production into military goods.

Böhm-Bawerk does not write specifically on war, so we have constructed these points from his capital theory. However, Böhm-Bawerk's personal and political history matches what he (and we) wrote. He served multiple terms as the Minister of Finance for Austria in the late nineteenth and early twentieth centuries and his policies clearly did not demonstrate a belief that increased public spending benefits the economy. For example, he never wavered from support of a balanced government budget. He opposed large-scale military spending by the Austrian army, whose leaders demanded this even before the outbreak of World War I. Schumpeter (1925) noted that Böhm-Bawerk's reticence to boosting military spending was not ideological, but rather reflected his belief that government should not spend more than it takes in via taxation. Conversely, Gerschenkron (1977) severely criticizes Böhm-Bawerk for his unwillingness to increase government spending (especially on public works projects) without increasing taxes. This lack of spending, Gerschenkron claims, caused Austria to be economically backwards.

\section{Wieser, Gossen's laws, and alternative cost}

The third economist in the early Austrian triumvirate was Friedrich von Wieser Wieser's work bears the clear influences of both Menger and Hermann Heinrich Gossen, a German economist of the early 1800s whose work was overshadowed and ignored by the German economic historicists. Gossen's First, Second, and Third Laws 
are deeply ingrained in the Austrian tradition, and particularly in Wieser's work. Gossen's First Law, anticipating the marginalist revolution by 17 years, is today called the law of diminishing marginal utility. Briefly, the utility derived by serial consumption of a homogeneous good diminishes with each marginal unit. This is also sometimes referred to as Gossen's Law of Satiation (Wieser, 1971, pp. 7-10). In fact, this is similar to Menger's own contribution to the marginalist revolution (Menger, 1976, pp. $128 \mathrm{ff}$.). To the extent that war goods could be called (Mengerian) goods at all, they still are subject to Gossen's First Law. Repeated uses of such goods ultimately have diminishing returns, especially in aggressive war, as the original strategic purpose of attacks over time tend to deteriorate into just plain destruction with no real strategic value.

Gossen's Second Law is what today is known as the equi-marginal principle. Wieser explains that the

"greatest possible enjoyment ... could not be reached if the separate branches of expenditure were not adequately weighed against each other ... Every overstepping in one branch will have to be paid for in another, which other, as represented by a higher degree on the scale of wants, will impose a sacrifice greater than the enjoyment got from it."

Menger made a similar argument in his Principles (1976, pp. $122 \mathrm{ff})$. In his table demonstrating the progressive satisfaction of several different needs, he shows that a person is likely to shift from satisfying some need A to satisfying some need B long before the satiation level of $\mathrm{A}$ is reached. Rather, he points out, each subsequent satisfaction of A must be weighed against the possibility of satisfying needs B, C, D, and so on. At the margin, he argues, resources are applied to meeting the need from which the most utility is derived, thereby keeping all needs in a more or less equivalent state. If satisfaction of need $\mathrm{A}$ is further progressed than is satisfaction of the other needs, then no additional resources will be applied to need A until the other needs are more fully and equally satisfied.

Again, we apply this principle to war. Austrians believe that a win-at-all-costs mentality is unacceptable because it implies that all other alternatives have no value. If alternatives are possessed of positive value, then a win-at-all-costs military policy, like one which demands unconditional surrender, likely costs society more than it gains via military victory. A nation should acquire war goods and wage war to the extent that such goods and war meet the equi-marginal principle. When more war goods are created than can be justified, it is necessary to stop producing such goods and waging such war until the marginal utilities of all other choices have diminished sufficiently to equal the diminished utility associated with the war.

Gossen's Third Law is that scarcity is necessary for goods to have economic value. If a good is not scarce, there is no opportunity cost associated with its use. Menger distinguishes between value and marginal utility by applying scarcity to marginal utility to demonstrate value (Menger, 1976, chapter 3). Wieser discusses the difference between goods that exist in "superfluity" and those that do not, pointing out that those existing in abundance are valueless because nothing is sacrificed by their use. Such goods can be used without engaging in economizing behavior, being used and destroyed with no regard to their value because more such goods can be acquired easily and virtually costlessly.

Wars pervert Gossen's Third Law inasmuch as military campaigns intentionally destroy capital goods, civilian infrastructure, and human beings, things (and beings) that are valuable. Aggressors destroy things regardless of their value. For example, the Allied bombing of Dresden, Germany, in 1945, destroyed centuries worth of priceless art and architecture, and this was done despite Dresden's lack of strategic military value. The purpose of the bombing was to kill and terrorize German civilians.

Adding to Gossen and Menger, Wieser made three important contributions to economic thinking. His first contribution is the concept of alternative cost, a precursor to opportunity cost. This is related to Gossen's Third Law because all goods that are not available in superfluity - that is, all goods that are scarce-are desired in quantities greater than are available. Any scarce good that is used in one way can have alternative uses. War highlights multiple alternative costs. First, there is the alternative cost of acquiring weapons, instead of spending for schools, hospitals, roads, consumer goods, and more. Second, we see that military personnel, including soldiers, noncombat military personnel, and nonmilitary support staff, could have been deployed in alternative ways, producing those very schools, hospitals, roads, and consumer goods that now cannot be produced because both the labor and the financial resources have been diverted to military spending. Third, we see in the destruction wreaked by military activities an alternative cost. Everything destroyed by the military comes with its own set of alternative costs. Had these things not been destroyed, they could have continued to meet human needs.

Henry Hazlitt, in Economics in One Lesson (1979), discusses the opportunity cost of war in chapter 3, which he gives the sarcastic title "The Blessings of Destruction." Hazlitt says that the economic stimulus of war is an example of the Broken Window fallacy in which people mistakenly identify the repairing of broken windows as a source of new wealth. Hazlitt, following Frederic Bastiat, Menger, and Wieser, points out that as things are destroyed, their productive services are lost. Rather than seeing the replacement cost as a benefit to society (on the argument that we had to produce these things, thereby stimulating the economy), we need to recognize the full picture. In replacing those things destroyed, we utilize scarce resources that have alternate uses. To employ them in rebuilding what has been destroyed by war is to employ them twice to the same end. It makes no sense to claim that there is a benefit to using the original amount of resources to produce these goods once, and then using that same amount of resources over again to reproduce these goods.

Wieser's second contribution, again building on Menger and Gossen, was coining the phrase "marginal utility," a mainstay in almost all schools of economics today. 
Like Menger, Wieser held that value was subjective, ${ }^{5}$ a lasting hallmark of Austrian economics. Further, like Menger and other Austrians, he held that a price system is vital to an economy, and that even a socialist economy would need such a system, a point with which later critics of the Austrian School, such as Oskar Lange, agreed. Unlike the other Austrians, however, Wieser also believed that inequalities of wealth distorted the price system to a point where prices did not necessary reflect the "natural values" as determined by marginal utility, and he believed that a price system functioned as a second-best solution, a necessary evil.

Third, Wieser in his 1889 [1956] work, Natural Value, also coined the term "imputation." Like Menger, he recognized that the value of the factors of production was imputed from the value of the final products they helped to create. When we combine imputation with alternative cost, we recognize that each factor of production can be used to produce more than one good. For example, instead of using our resources to build a farm equipment factory, we could have applied those resources toward building a factory that makes other goods. If goods have value, then the factories and other resources used to produce those goods have value imputed to them. In a free market economy, all values come from consumer decisions. As consumers desire one good more than another, that desire translates into demand changes for the good, which are then imputed to the inputs for the good.

But war goods are not selected by consumers in the free market. Rather, governments select war goods to attain political ends. If consumers derive little or no value from war goods, then the factories and other inputs that produce those goods have little or no value imputed to them. This implies that less value is imputed to these factories than would be imputed to factories that produce other goods. The alternative cost is too high, and the equi-marginal principle is being ignored by the government to the detriment of the consumers and taxpayers. Assume that the farm plant is taken over during a war and turned into a factory that makes tanks and other weapons. First, capital goods and certainly final goods are not perfectly interchangeable; the capital lines will have to be adjusted, and that will require investment and the use of scarce resources. Second, no longer can these factors operate according to the way they are valued, as value in a war economy has nothing to do with consumer preferences. Third, even after a war ends, the war-created capital is not useful in a civilian economy, which means the factories once again must be re-tooled. That also means that the factors that were deemed valuable by war authorities when the war production regime exists now must be re-assessed according to an economy based once again upon consumer preferences.

One can take Austrian concepts and derive a comprehensive view as to why war and economic prosperity are mutually exclusive. Earlier, we interpreted Mengerian analysis to classify war goods as imaginary goods, things that do not meet human needs. (Obviously, if a war weapon permits one to defend one's property and loved ones from invaders, it is a Mengerian good, but few weapons of war these days can be termed purely defensive.) In the Austrian view, war cannot stimulate an economy, but rather distorts it. Furthermore, the longer war and the dislocation of the production structure go on, the more difficult it will be for the consumer-based structure of production to reassert itself after the war, and government controls and orders, have ended.

\section{Conclusion}

Wieser and the other Austrians were not antiwar activists. In fact, Wieser served as Austrian Minister of Commerce during World War I, although, according to Mises (1984, p. 6), his powers were quite limited and his decisions “secondary." However, the Austrian economic doctrines with their emphasis upon nonintervention, subjective value, and opportunity cost clearly would place them against anyone, economist or otherwise, who would support war as a means to boost an economy, given that war itself is the most radical of all government interventions.

The early Austrians did not even see government economic intervention as zero-sum, but as negative-sum because of the displacement of capital, the alteration of the structure of production, the disregard for alternative cost, and the loss of value engendered by government intervention. Even if the Austrian economists might have seen a particular war as being justified for political reasons, nonetheless they did not think of government intervention as creating an overall positive benefit for the economy.

The early Austrian economists were a product of the liberal order of the nineteenth century, a time of relative peace on the European continent when borders were relatively open and the gold standard had not come to the point of crisis it would reach with the onset of World War I. Their methodology was based upon individual choice, entrepreneurship, subjective valuation, marginal utility, imputation, and opportunity cost. In that regard, they held on to the older, classical, view that as the economies of nations grew and people became wealthier, civilization itself was advanced, even as they were in the forefront of the marginalist revolution.

Although they clearly were not pacifists, nonetheless the methodology upon which the Austrian founders built their economic thought would challenge the viewpoint that war can bring net economic benefits to society. The next generation, including von Mises and von Hayek, would further attack the economic foundations of war, and subsequent generations of economists in the Austrian tradition, including Murray Rothbard and Hans-Hermann Hoppe, would become even more hostile to the state intervention known as war.

\section{Notes}

Scott A. Kjar, formerly at the Department of Economics, University of Dallas, Dallas, Texas, may be reached at scottakjar@yahoo.com. William L.Anderson is a the Department of Economics, Frostburg State University, Frostburg, Maryland. The 
corresponding author, he may be reached at banderson@frostburg.edu. The authors thank Sam Bostaph for comments. All errors are the responsibility of the authors.

1. Modern Austrian thinkers, such as Murray Rothbard (1993), distinguish between a just war and an unjust or aggressive war.

\section{See Anderson (2000).}

3. "Secretary Rumsfeld Town Hall Meeting in Kuwait." 8 December 2004.

http://www.defenselink.mil/transcripts/transcript.aspx?transcriptid=1980 [accessed 11 September 2009].

4. Wieser (1956, book I, p. 14).

5. Ekelund and Hebert (1990).

\section{References}

Anderson, W.L. 2000. "Say's Law: Were the Critics Right?” Conference paper. Austrian Scholars Conference (March). Auburn, Alabama.

Böhm-Bawerk, E. 1959. Capital and Interest. (Three volumes in one.) G.D. Huncke and H.F. Sennholz, trans. South Holland, IL: Libertarian Press.

Caplan, B. 1999. "The Austrian Search for Realistic Foundations." Southern Economic Journal. Vol. 65, No. 4, pp. 823-838.

Ekelund, R.B., Jr. and R.F. Hebert. 1990. A History of Economic Theory and Method. New York: McGraw-Hill.

Garrison, R. 1999. “Eugen von Böhm-Bawerk: Capital, Interest, and Time,” pp. 113122 in R.G. Holcombe, ed. 15 Great Austrian Economists. Auburn, AL: Ludwig von Mises Institute.

Gerschenkron, A. 1977. An Economic Spurt That Failed: Four Lectures in Austrian History. Princeton, NJ: Princeton University Press.

Hazlitt, H. 1979. Economics in One Lesson. Westport, CT: Arlington House.

Higgs, R. 1992. "Wartime Prosperity? A Reassessment of the U.S. Economy in the 1940s." Journal of Economic History. Vol. 52, No. 1, 41-60..

Menger, C. 1976. Principles of Economics. New York: New York University Press.

Mises, L. von. 1944. Omnipotent Government: The Rise of the Total State and Total War. New Haven, CT: Yale University Press.

Mises, L. von. 1984. The Historical Setting of the Austrian School. Auburn, AL: Ludwig von Mises Institute.

Rothbard, M.N. 1993. Man, Economy, and State. Auburn, AL: Ludwig von Mises Institute.

Say, J.-B. 1971. A Treatise on Political Economy. New York: Augustus M. Kelley.
Schumpeter, J.A. 1925. Eugen von Böhm-Bawerk. Vienna: Neue Österreichische Biographie, Vol. 2.

Shirer, W.L. 1941. Berlin Diary. New York: Alfred A. Knopf.

Smith, A. 1976. An Inquiry into the Nature and the Causes of the Wealth of Nations. Indianapolis, IN: Liberty Press.

Sowell, T. 1985. Marxism: Philosophy and Economics. New York: Quill.

Wieser, F. 1956 [1889]. Natural Value. A. Malloch, trans. and W. Smart, ed. New York: Kelley and Millman. 